\title{
Effects of the Pillars of Competitiveness on the Competitive Positions of Poland and the Visegrad Group Countries in the Post-Accession Period ${ }^{1}$
}

\author{
Edward Molendowski \\ University Professor, Ph.D., Krakow University of Economics, Faculty of Economics \\ and International Relations, Department of International Economic Relations \\ Krakow, Poland, e-mail: edward.molendowski@uek.krakow.pl
}

\section{Paweł Folfas}

Assistance Professor Ph.D., Warsaw School of Economics, Collegium of World Economy, Institute of International Economics, Warsaw, Poland e-mail:pfolfa@sgh.waw.pl

\begin{abstract}
The article presents the results of an analysis aimed at assessing the effects of fundamental factors (pillars) on the international positions and competitiveness of the economies of Poland and the other Visegrad Group (V4) countries. It attempts to verify the hypothesis that in shaping their international competitive position, the V4 economies should rely more on efficiency enhancers as well as innovation and sophistication factors. The competitive positions of the economies covered and the changes thereof were determined on the basis of the Global Competitiveness Report (GCR) editions published by the World Economic Forum. The period under examination includes the years 2004-2017, but owing to the lack of comparable data, it was narrowed to the years 2006-2017.

The article ends with a summary of the most important conclusions from the analysis.
\end{abstract}

Keywords: international economic competitiveness, pillars of the competitiveness of the Polish economy, Poland of the V4 countries

JEL: E2, E6, F4, F5

1 The project was financed by the National Science Centre, project registration number: DEC 2015/17/B/HS4/02075. 


\section{Introduction}

As in the case of other new EU Member States in the post-accession period, Poland experienced a number of successes and failures. Joining the EU triggered changes in addition to those initiated in the early 1990s. The first years of membership allowed these countries to build relatively firm and stable foundations for further development, which became the main determinant of strengthening the international competitive positions of their economies.

The study presented in the article mostly aims to assess the effects of the fundamental factors (pillars) on the international positions and competitiveness of the economies of Poland and the other Visegrad Group (V4) countries.

It attempts to verify the hypothesis that in shaping their international competitive position, the V4 economies should rely more on efficiency enhancers as well as innovation and sophistication factors. The competitive positions of the economies covered and the changes thereof were determined on the basis of the Global Competitiveness Report (GCR) editions published by the World Economic Forum. The period under examination includes the years 2004-2017, but owing to the lack of comparable data, it was narrowed to the years 2006-2017.

The article presents part of a more extensive study of the importance of international linkages to shaping the long-term economic competitiveness of the new EU Member States, conducted within a research grant financed by the National Science Centre.

\section{The substance and methods of measuring international economic competitiveness}

The increased interest in the concept of countries' international competition gave rise to a number of approaches to this economic phenomenon. Attempts to define it usually refer to relative national productivity (Krugman 1994, pp. 28-44; Porter and Rivkin 2012, pp. 54-62), the attractiveness of the location for mobile factors of production (Siebert 2000, pp. 191-200; Kancs 2011, pp. 191-200) and/or to the ability to derive greater (than other countries) benefits from participating in world trade and in the international division of labour (Weresa 2012). Therefore, in order to describe the substance of the phenomenon of competitiveness, one can assume that it is a country's relative ability to achieve stable and sustainable growth in the conditions of an open economy (Ezalea-Harrison 2005, pp. 80-87; Thore and Tarverdyan 2016, pp. 108-114 as in: Żmuda 2016).

In the research approach adopted in this article, we understand competitiveness as the ability to achieve development goals. The fundamental objective is assumed to be the ability to improve the welfare of citizens, which - for a catching-up economy - relates to the rate of convergence, i.e., bridging the development gap (for more see: Żmuda 2016). 
An assessment of international economic competitiveness involves determining the competitive position of an economy in static terms, at a point in time (Bossak 2000), or as dynamic competitiveness seen as the ability to improve the economy's position in the longer term (Misala, Misztal, Młynarzewska and Siek 2008).

In recent years, a number of measures of international competitiveness as well as measurement methods have been proposed (Żmuda 2017). Determinants of the competitiveness of particular countries have been addressed by various scholars and international research centres (Weresa 2012; Wysokińska 2001; Molendowski 2017a). One of the most comprehensive and most frequently quoted rankings can be considered that of the international competitiveness of economies (The Global Competitiveness Report). It is the product of a comparative study of economic development conditions in individual countries prepared on an annual basis by the World Economic Forum. The countries covered are ranked in terms of competitiveness measured by an index developed for this purpose. In the most recent study (2017), it is calculated on the basis of 114 factors, grouped into 12 pillars, and divided into three categories with regard to specific countries: basic requirements, efficiency enhancers, as well as innovation and sophistication factors. For each determinant, individual countries receive scores of 1 to 7, where 1 and 7 denote the lowest and the highest possible scores, respectively (WEF, 2017).

In the WEF ranking, basic requirements are of key importance to economies whose development is mostly based on traditional factors of production (their GDP per capita does not exceed USD 2,000). Efficiency enhancers are crucial for economies mainly driven by investment (GDP per capita of USD 3,000 to USD 17,000). Innovation and sophistication factors are particularly vital to countries whose development is innovation-driven. Those are countries at the top (third) stage of economic development (their GDP per capita exceeds USD 17,000). It is worth emphasising that efficiency enhancers were assigned relatively the highest weight among the determinants of a country's competitive position. Simultaneously, basic requirements play a relatively significant role in defining the competitive position of the lowest-income countries (Molendowski 2017b).

\section{Changes of the competitive position of Poland against the backdrop of the V4 countries}

According to the results of the economic competitiveness studies carried out by the World Economic Forum (WEF), in the first years following EU accession Poland ranked relatively low in terms of international position and competitiveness (against the backdrop of the countries covered) (cf. Table 1).

In 2004, in terms of competitiveness, Poland's economy ranked as low as $60^{\text {th }}$ (with a score of 3.98). It is worth emphasising that in the first years after accession - until 2010 - Poland significantly improved its position in the ranking. Particularly favour- 
able developments were observed in 2004-2006. In those three years, Poland moved up from $60^{\text {th }}$ to $45^{\text {th }}$ place among the countries covered. In 2007-2008, its position deteriorated to a certain degree, but 2009-2010 again witnessed considerable improvement. As a result, in 2010, Poland ranked as high as $39^{\text {th }}$. The following years saw a reversal, and the downward trend stopped as late as $2016\left(36^{\text {th }}\right.$ place, a score of 4.56$)$. Unfortunately, in 2017, there was further deterioration (down to $39^{\text {th }}$ place with a score of 4.59). However, it is worth stressing that in the whole post-accession period. Poland improved its rank by as many as 21 spots. The most successful period was that before 2010 (as illustrated in Figure 1).

Table 1. The position of Poland against the backdrop of the $\vee 4$ countries in the competitiveness studies conducted by the World Economic Forum in 2004-2017

\begin{tabular}{|l|c|c|c|c|c|c|c|c|}
\hline \multirow{2}{*}{ Ranking } & \multicolumn{9}{|c|}{ Rank } & \multicolumn{4}{c|}{ GCI score } \\
\cline { 2 - 9 } & CZ & HU & PL & SK & CZ & HU & PL & SK \\
\hline $2004-2005$ & 40 & 39 & 60 & 43 & 4.55 & 4.56 & 3.98 & 4.43 \\
\hline $2005-2006$ & 38 & 39 & 51 & 41 & 4.42 & 4.38 & 4.00 & 4.31 \\
\hline $2006-2007$ & 31 & 38 & 45 & 36 & 4.67 & 4.49 & 4.39 & 4.54 \\
\hline $2007-2008$ & 33 & 47 & 51 & 41 & 4.58 & 4.35 & 4.28 & 4.45 \\
\hline $2008-2009$ & 33 & 62 & 53 & 46 & 4.62 & 4.22 & 4.28 & 4.40 \\
\hline $2009-2010$ & 31 & 58 & 46 & 47 & 4.67 & 4.22 & 4.33 & 4.31 \\
\hline $2010-2011$ & 36 & 52 & 39 & 60 & 4.57 & 4.33 & 4.51 & 4.25 \\
\hline $2011-2012$ & 38 & 48 & 41 & 69 & 4.52 & 4.36 & 4.46 & 4.19 \\
\hline $2012-2013$ & 39 & 60 & 41 & 71 & 4.51 & 4.30 & 4.46 & 4.14 \\
\hline $2013-2014$ & 46 & 63 & 42 & 78 & 4.43 & 4.25 & 4.46 & 4.10 \\
\hline $2014-2015$ & 37 & 60 & 43 & 75 & 4.53 & 4.28 & 4.48 & 4.15 \\
\hline $2015-2016$ & 31 & 63 & 41 & 67 & 4.69 & 4.25 & 4.49 & 4.22 \\
\hline $2016-2017$ & 31 & 69 & 36 & 65 & 4.72 & 4.20 & 4.56 & 4.28 \\
\hline $2017-2018$ & 31 & 60 & 39 & 59 & 4.77 & 4.33 & 4.59 & 4.33 \\
\hline Change 2017/2004 & 9 & -21 & 21 & -16 & 0.22 & -0.23 & 0.61 & -0.1 \\
\hline
\end{tabular}

Source: WEF (2016); WEF (2017).

An important element of the analysis is to compare the scores obtained by Poland with those of the other Visegrad Group countries. It is common knowledge that in the post-accession period the socio-economic situation in the countries concerned was similar to that observed in Poland. However, they varied widely in terms of competitiveness scores (cf. Table 1 and Figure 1). At the beginning of the period covered, Poland's competitiveness $\left(60^{\text {th }}\right.$ place) was assessed as being much worse than in the case of the Czech Republic, Hungary and Slovakia (ranked $40^{\text {th }}, 39^{\text {th }}$, and $43^{\text {rd }}$ respectively). In the following years, until 2007, Poland continued to be ranked lower than the other V4 countries. In 2008, Hungary and 2009 Slovakia were ranked below Poland, and such a situation (lower ranks of Hungary and Slovakia) was observed until the end of the period under analysis (2017). Therefore, throughout the period covered, only the Czech Republic outperformed Poland. In 2017, Poland was 
ranked below the Czech Republic ( $31^{\text {st }}$ place) but significantly higher than Hungary and Slovakia (ranked $60^{\text {th }}$ and $59^{\text {th }}$ respectively).

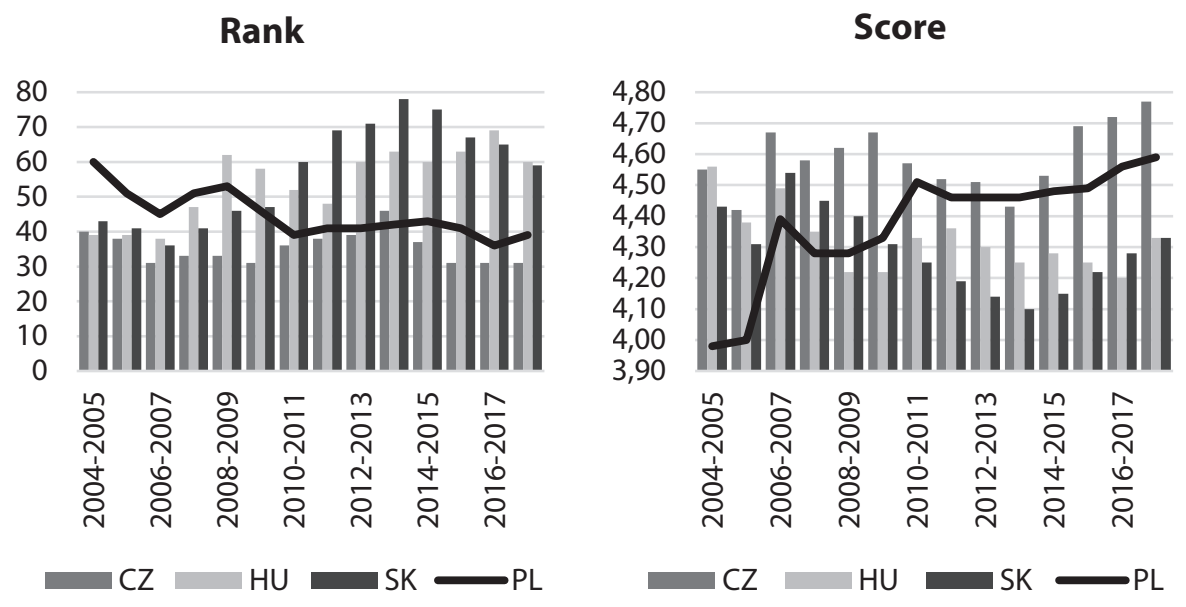

Figure 1. Changes in the competitive position of Poland against the backdrop of the V4 countries in 2004-2017

Source: Own study based on data as in Table 1.

It is worth emphasising that the analysis of the data presented in Table 1 (and illustrated in Figure 1) unequivocally shows that, against the backdrop of the countries covered, Poland was the most successful in improving its international economic competitiveness in the post-accession period. Whereas Poland jumped by as many as 21 spots (by 0.61) in the WEF ranking, the Czech Republic moved up by nine positions (by 0.22). Simultaneously, Hungary and Slovakia dropped by 21 and 16 places, respectively. Due to the above-mentioned developments, from the country with the worst position in 2004, Poland became one enjoying a much more favourable position in comparison with two of its partners (Hungary and Slovakia).

\section{Determinants of the competitive position of Poland against the backdrop of the V4 countries}

\section{Changes in the indices presented in the Global Competitiveness Reports}

As already mentioned, the comparative analysis of conditions of the economic development of countries conducted on an annual basis by the World Economic Forum results in a ranking of international economic competitiveness presented in the Global Competitiveness Report. It is worth emphasising that among the determinants of a country's competitive position, the GCR authors assign relatively the high- 
est weight to efficiency enhancers. Simultaneously, for them, basic requirements play a relatively significant role in defining the competitive position of the lowest-income countries (WEF, 2017). Table 2 contains data concerning the effects of specific determinants (pillars) on the competitive positions of Poland and the other V4 countries.

Table 2. Scores for particular groups of pillars (sub-indices) of the competitive positions of the V4 countries in 2006 and $2017^{2}$

\begin{tabular}{|c|c|c|c|c|c|c|c|c|c|c|c|c|}
\hline \multirow{3}{*}{ Pillars } & \multicolumn{12}{|c|}{ Rank } \\
\hline & \multicolumn{4}{|c|}{2006} & \multicolumn{4}{|c|}{2017} & \multicolumn{4}{|c|}{ Change 2017/2006 } \\
\hline & $\mathrm{CZ}$ & $\mathrm{HU}$ & PL & SK & $\mathrm{CZ}$ & $\mathrm{HU}$ & $\mathrm{PL}$ & SK & $\mathrm{CZ}$ & HU & PL & SK \\
\hline GCl & 31 & 38 & 45 & 36 & 31 & 60 & 39 & 59 & 0 & -22 & 6 & -23 \\
\hline A. & 39 & 50 & 54 & 47 & 30 & 64 & 45 & 52 & 9 & -14 & 9 & -5 \\
\hline B. & 28 & 32 & 40 & 31 & 29 & 45 & 34 & 44 & -1 & -13 & 6 & -13 \\
\hline \multirow[t]{4}{*}{ C. } & 27 & 33 & 48 & 43 & 32 & 79 & 59 & 56 & -5 & -46 & -11 & -13 \\
\hline & \multicolumn{12}{|c|}{ GCl score } \\
\hline & \multicolumn{4}{|c|}{2006} & \multicolumn{4}{|c|}{2017} & \multicolumn{4}{|c|}{ Change 2017/2006 } \\
\hline & $\mathrm{CZ}$ & HU & PL & SK & CZ & HU & PL & SK & $\mathrm{CZ}$ & HU & PL & SK \\
\hline $\mathrm{GCl}$ & 4.67 & 4.49 & 4.39 & 4.54 & 4.77 & 4.33 & 4.59 & 4.33 & 0.11 & -0.17 & 0.21 & -0.21 \\
\hline A. & 4.94 & 4.71 & 4.62 & 4.76 & 5.35 & 4.65 & 4.99 & 4.83 & 0.41 & -0.06 & 0.37 & 0.06 \\
\hline B. & 4.59 & 4.48 & 4.33 & 4.50 & 4.86 & 4.44 & 4.65 & 4.46 & 0.27 & -0.03 & 0.32 & -0.05 \\
\hline C. & 4.39 & 4.06 & 3.73 & 3.82 & 4.24 & 3.52 & 3.75 & 3.76 & -0.15 & -0.54 & 0.03 & -0.06 \\
\hline
\end{tabular}

Pillars: A. Basic requirements sub-index; B. Efficiency enhancers sub-index; C. Innovation and sophistication factors sub-index.

Source: Own study based on data as in Table 1.

It follows from the data presented in Table 2 that in 2006 the competitive positions of the $\mathrm{V} 4$ countries were mostly driven by basic requirements. In that category, their GCI score was relatively the highest (4.52). Basic requirements were followed by efficiency enhancers (4.48). Simultaneously, innovation and sophistication factors played the least important role (4.0).

Until 2017, there was no improvement in the situation. The V4 countries, as a whole, even deteriorated their competitive position by as many as ten spots in the WEF ranking (mainly due to the significantly worse ranks of Hungary and Slovakia). Basic requirements continued to mostly shape their competitive position. The average GCI score even rose by $0.2 \mathrm{pp}$, whereas in the case of efficiency enhancers, there was an increase of $0.13 \mathrm{pp}$ and the innovation and sophistication factors sub-index dropped by $0.18 \mathrm{pp}$. Those changes must be regarded as definitely unfavourable. According to the GCR authors, the V4 countries, whose GDP per capita ranged from USD 3,000 to USD 17,000 in the period covered, should build their competitive positions based on efficiency enhancers. Unfortunately, in the past ten years, the situation has not changed.

2 The data presented in this table only cover the period from 2006 as the rankings for prior years were based on a different classification of pillars of the competitive positions of the countries under analysis. 


\section{The effects of specific pillars - a statistical analysis}

The statistical analysis presented in this article was based on weighted contributions of particular pillars to change in the GCI for the Visegrad Group (V4) countries (the 2017-2018 edition in comparison with the 2006-2007 edition) ${ }^{3}$. Therefore, the method employed in the analysis was the one proposed by the authors of the Global Competitiveness Report. In the Report, weighted contributions are products of changes in pillar scores and pillar weights. The weights assigned by the creators of the competitiveness reports depend on the stage of development of the country concerned as classified in individual editions. With the exception of Hungary, in specific years from the 2006-2018 period, the V4 countries were ranked among different groups of countries. Therefore, the weights of individual pillars changed over time and, for the purposes of the analysis, weighted average pillar weights were computed (see the notes below, Tables 3 to 6 ).

Table 3. The contributions of particular pillars to the change in the overall GCl score for Poland

\begin{tabular}{|l|c|c|c|}
\hline \multicolumn{1}{|c|}{ Pillars } & $\begin{array}{c}\text { Change (the } \\
\text { 2017-2018 edition } \\
\text { in comparison with } \\
\text { the 2006-2007 } \\
\text { edition) }\end{array}$ & $\begin{array}{c}\text { Importance } \\
\text { of the pillar } \\
\text { (pillar weight) } \\
\text { to the overall } \\
\text { GCl score (in \%) }\end{array}$ & $\begin{array}{c}\text { Weighted } \\
\text { contribution } \\
\text { to change (the } \\
\text { 2017-2018 edition } \\
\text { in comparison with } \\
\text { the 2006-2007 } \\
\text { edition) }\end{array}$ \\
\hline 1. Institutions & 0.2 & $8.28^{*}$ & 0.0166 \\
\hline 2. Infrastructure & 1.41 & $8.28^{*}$ & 0.1167 \\
\hline 3. Macroeconomic environment & 0.1 & $8.28^{*}$ & 0.0083 \\
\hline 4. Health and primary education & -0.24 & $8.28^{*}$ & -0.0199 \\
\hline 5. Higher education and training & 0.25 & $8.33^{* *}$ & 0.0208 \\
\hline 6. Goods market efficiency & 0.29 & $8.33^{* *}$ & 0.0242 \\
\hline 7. Labour market efficiency & -0.3 & $8.33^{* *}$ & -0.0250 \\
\hline 8. Financial market development & 0.07 & $8.33^{* *}$ & 0.0058 \\
\hline 9. Technological readiness & 1.5 & $8.33^{* *}$ & 0.1250 \\
\hline 10. Market size & 0.11 & $8.33^{* *}$ & 0.0092 \\
\hline 11. Business sophistication & 0.08 & $8.44^{* * *}$ & 0.0068 \\
\hline 12. Innovation & -0.03 & $8.44^{* * *}$ & -0.0025 \\
\hline
\end{tabular}

* $10 \%$ in the 2006-2007, 2007-2008 editions of the report and $7.93 \%$ in the other editions covered;

** $8.33 \%$ in all the editions of the report covered;

*** 5\% in the 2006-2007, 2007-2008 editions of the report and 9.15\% in the other editions covered. Source: Own study based on data contained in the 2006-2007 to 2017-2018 editions of the Global Competitiveness Report.

3 Due to additional calculations in the estimation of the overall Global Competitiveness Index (GCI), the sum of weighted contributions of specific pillars to the change in the $\mathrm{GCl}$ does not accurately reflect the nominal change in the overall $\mathrm{GCl}$. 
As follows from the data presented in Table 3, in the case of Poland, the most distinct improvement was noted for pillars 2 and 10. The scores in the two pillars are positively correlated (with the linear and non-linear correlation coefficients at ca. $86 \%$ and nearly $88 \%$ respectively), which means that an improvement in one area is accompanied by an improvement in the other. It seems that investments in the road and rail transport network are related to better infrastructure and technological readiness in Poland.

In contrast, the most significant deterioration was observed in pillars 4 and 7. It is attributable to the numerous but still unsuccessful reforms of the Polish health service as well as to the relatively strong position of trade unions (frequently there is a significant number of them, in conflict with each other, even in a single enterprise) in certain industries and failures to change that state of affairs. The scores in the two pillars are not correlated, which makes the above-mentioned causes more probable. As regards the other eight pillars, the period covered saw no significant developments (a slight deterioration in the case of one pillar, only minor improvement in the rest of them).

Table 4. The contributions of particular pillars to the change in the overall GCl score for the Czech Republic

\begin{tabular}{|l|c|c|c|}
\multicolumn{1}{|c|}{ Pillars } & $\begin{array}{c}\text { Change (the } \\
\text { 2017-2018 edition } \\
\text { in comparison with } \\
\text { the 2006-2007 } \\
\text { edition) }\end{array}$ & $\begin{array}{c}\text { Weighted } \\
\text { Importance } \\
\text { of the pillar } \\
\text { (pillar weight) } \\
\text { to the overall } \\
\text { GCl score (in \%) }\end{array}$ & $\begin{array}{c}\text { Wontribution } \\
\text { congenge (the } \\
\text { to chang edition } \\
\text { in comparison with } \\
\text { the 2006-2007 } \\
\text { edition) }\end{array}$ \\
\hline 1. Institutions & 0.27 & $5.06^{*}$ & 0.0137 \\
\hline 2. Infrastructure & 0.19 & $5.06^{*}$ & 0.0096 \\
\hline 3. Macroeconomic environment & 0.80 & $5.06^{*}$ & 0.0404 \\
\hline 4. Health and primary education & 0.36 & $5.06^{*}$ & 0.0182 \\
\hline 5. Higher education and training & 0.30 & $8.33^{* *}$ & 0.0250 \\
\hline 6. Goods market efficiency & -0.03 & $8.33^{* *}$ & -0.0025 \\
\hline 7. Labour market efficiency & -0.13 & $8.33^{* *}$ & -0.0108 \\
\hline 8. Financial market development & 0.44 & $8.33^{* *}$ & 0.0367 \\
\hline 9. Technological readiness & 1.12 & $8.33^{* *}$ & 0.0933 \\
\hline 10. Market size & -0.06 & $8.33^{* *}$ & -0.0050 \\
\hline 11. Business sophistication & -0.19 & $14.89^{* * *}$ & -0.0283 \\
\hline 12. Innovation & -0.10 & $14.89^{* * *}$ & -0.0149 \\
\hline
\end{tabular}

* 5.33\% in the 2006-2007, 2007-2008 editions of the report and 5\% in the other editions covered;

** $8.33 \%$ in all the editions of the report covered;

*** 14.35\% in the 2006-2007, 2007-2008 editions of the report and 15\% in the other editions covered. Source: Own study based on data as in Table 3.

In the case of the Czech Republic, the most significant improvement was noted in pillars 3 and 9 (see Table 4). The scores for the two pillars are positively correlated (with the linear and non-linear correlation coefficients at ca. 69\% and nearly $74 \%$ 
respectively). At the same time, the most abrupt deterioration was related to pillars 11 and 12 . The scores in the two pillars are positively correlated, and the correlation is stronger than in the case of pillars 3 and 9 (with the linear and non-linear correlation coefficients at ca. 86\%). It means that deterioration in one area is accompanied by deterioration in the other. It must be seen as particularly alarming since the fundamental recommendation for the V4 countries as economies catching up with the EU-15 is specifically to increase the innovation of businesses, industries and, thus, the national economies. Therefore, improvements in the macroeconomic environment and business sophistication appeared to be insufficient to effectively shape the competitive position of the Czech economy.

Table 5. The contributions of particular pillars to the change in the overall competitiveness $\mathrm{GCl}$ score for Slovakia

\begin{tabular}{|l|c|c|c|}
\hline \multicolumn{1}{|c|}{ Pillars } & $\begin{array}{c}\text { Change (the } \\
\text { 2017-2018 edition } \\
\text { in comparison with } \\
\text { the 2006-2007 } \\
\text { edition) }\end{array}$ & $\begin{array}{c}\text { Importance } \\
\text { of the pillar } \\
\text { (pillar weight) } \\
\text { to the overall } \\
\text { GCl score (in \%) }\end{array}$ & $\begin{array}{c}\text { Weighted } \\
\text { contribution } \\
\text { to change (the } \\
\text { 2017-2018 edition } \\
\text { in comparison with } \\
\text { the 2006-2007 } \\
\text { edition) }\end{array}$ \\
\hline 1. Institutions & -0.47 & $6.02^{*}$ & -0.0283 \\
\hline 2. Infrastructure & 0.57 & $6.02^{*}$ & 0.0343 \\
\hline 3. Macroeconomic environment & -0.01 & $6.02^{*}$ & -0.0006 \\
\hline 4. Health and primary education & 0.15 & $6.02^{*}$ & 0.0090 \\
\hline 5. Higher education and training & 0.09 & $8.33^{* *}$ & 0.0075 \\
\hline 6. Goods market efficiency & -0.11 & $8.33^{* *}$ & -0.0092 \\
\hline 7. Labour market efficiency & -0.72 & $8.33^{* *}$ & -0.0600 \\
\hline 8. Financial market development & -0.40 & $8.33^{* *}$ & -0.0333 \\
\hline 9. Technological readiness & 0.96 & $8.33^{* *}$ & 0.0800 \\
\hline 10. Market size & -0.08 & $8.33^{* *}$ & -0.0067 \\
\hline 11. Business sophistication & -0.02 & $12.98^{* * *}$ & -0.0026 \\
\hline 12. Innovation & -0.10 & $12.98^{* * *}$ & -0.0130 \\
\hline
\end{tabular}

* 10\% in the 2006-2007, 2007-2008 editions of the report, 5\% in the 2009-2010, 2012-2013, 2014-2015, 2015-2016 editions and 5.33\% in the other editions covered;

** $8.33 \%$ in all the editions of the report covered;

*** 5\% in the 2006-2007, 2007-2008 editions of the report, 15\% in the 2009-2010, 2012-2013, 2014-2015, 2015-2016 editions and 14.35\% in the other editions covered.

Source: Own study based on data as in Table 3.

As regards Slovakia, the most important improvement concerns pillars 2 and 9 (see Table 5). The scores for the two pillars are positively correlated (with the linear and non-linear correlation coefficients at ca. $60 \%$ and nearly $70 \%$ respectively). Therefore, it is a situation similar to that in Poland. Simultaneously, the most serious deterioration was related to pillars 1 and 7. The scores in the two pillars are positively correlated, and the correlation is stronger than in the case of pillars 2 and 9 (with the linear 
and non-linear correlation coefficients at ca. 80\%). It means that deterioration in one area is accompanied by deterioration in the other. It may indicate the worsened quality of institutions influencing economic efficiency in the period in question. The changes noted in the case of the other pillars were insignificant (minor improvements in two pillars and slightly deteriorated scores for six pillars).

Table 6. The contributions of particular pillars to the change in the overall competitiveness GCl score for Hungary

\begin{tabular}{|l|c|c|c|}
\hline \multicolumn{1}{|c|}{ Pillars } & $\begin{array}{c}\text { Change (the } \\
\text { 2017-2018 edition } \\
\text { in comparison with } \\
\text { the 2006-2007 } \\
\text { edition) }\end{array}$ & $\begin{array}{c}\text { Importance } \\
\text { of the pillar } \\
\text { (pillar weight) } \\
\text { to the overall } \\
\text { GCl score (in \%) }\end{array}$ & $\begin{array}{c}\text { Weighted } \\
\text { contribution } \\
\text { to change (the } \\
\text { 2017-2018 edition } \\
\text { in comparison with } \\
\text { the 2006-2007 } \\
\text { edition) }\end{array}$ \\
\hline 1. Institutions & -0.75 & $7.65^{*}$ & -0.0574 \\
\hline 2. Infrastructure & 0.51 & $7.65^{*}$ & 0.0390 \\
\hline 3. Macroeconomic environment & 0.60 & $7.65^{*}$ & 0.0459 \\
\hline 4. Health and primary education & -0.58 & $7.65^{*}$ & -0.0444 \\
\hline 5. Higher education and training & -0.54 & $8.33^{* *}$ & -0.0450 \\
\hline 6. Goods market efficiency & -0.04 & $8.33^{* *}$ & -0.0033 \\
\hline 7. Labour market efficiency & -0.29 & $8.33^{* *}$ & -0.0242 \\
\hline 8. Financial market development & -0.27 & $8.33^{* *}$ & -0.0225 \\
\hline 9. Technological readiness & 1.12 & $8.33^{* *}$ & 0.0933 \\
\hline 10. Market size & -0.19 & $8.33^{* *}$ & -0.0158 \\
\hline 11. Business sophistication & -0.72 & $9.70^{* * *}$ & -0.0698 \\
\hline 12. Innovation & -0.37 & $9.70^{* * *}$ & -0.0359 \\
\hline 7. & & & \\
\hline
\end{tabular}

* $7.65 \%$ in all the editions of the report covered;

** $8.33 \%$ in all the editions of the report covered;

*** $9.70 \%$ in all the editions of the report covered;

Source: Own study based on data as in Table 3.

As regards Hungary, the most important improvement concerns pillars 9, 3 and 2 (see Table 6). The scores for the three pillars are positively correlated (with the linear and non-linear correlation coefficients at ca. 74\%). The two most significant decreases in scores were noted in pillars 1 and 11. The scores for the two pillars show a very strong positive correlation (with the linear and non-linear correlation coefficients at ca. 98\%). It means that deterioration in one area is accompanied by deterioration in the other. Therefore, despite an improved macroeconomic environment and increased technological readiness, the institutional framework influencing the innovation of the economy distinctly worsened. The other pillars showed no significant changes. However, it seems interesting that slight decreases were observed in as many as six pillars. 


\section{Conclusion}

Thanks to accession to the European Union, Poland and the other V4 countries experienced rapid economic growth accompanied by restructuring and modernisation. It considerably improved the international competitive positions of their economies.

It follows from the review of major publications in the literature presented in the article that the competitiveness of an economy should be described dynamically, from the angle of the development of available (domestic and foreign) production factors, the ability to take opportunities related to ongoing globalisation and the adaptability of businesses, sectors and the economy as a whole to changing conditions in the external environment, thus - the achievement of development objectives. Such an approach to economic competitiveness was adopted by the authors of the Global Competitiveness Reports (GCR) prepared by researchers associated with the World Economic Forum.

The analysis of the GCR editions for 2004-2017 unambiguously demonstrates that, against the backdrop of the V4 countries, in the post-accession period, Poland was the most successful in improving the international competitive position of its economy. At the beginning of the period, Poland's competitiveness $\left(60^{\text {th }}\right.$ place $)$ was assessed as being much worse than in the case of the Czech Republic, Hungary and Slovakia. However, by 2017 , Poland had become a country ranked distinctly higher $\left(39^{\text {th }}\right)$ than the last two partners (Hungary and Slovakia, ranked $60^{\text {th }}$ and $59^{\text {th }}$, respectively). It was only slightly behind the Czech Republic $\left(31^{\text {st }}\right)$. It is worth adding that Hungary and Slovakia's positions in the ranking significantly deteriorated (down by as many as 21 and 16 spots).

It must be emphasised that in the period in question both Poland and the other countries under analysis built their competitive positions mostly on the basis of pillars classified as basic requirements. However, on account of the level of economic development (measured by GDP per capita), those countries should rely on efficiency enhancers or innovation and sophistication factors. In addition, it follows from the comparison of the Global Competitiveness Index scores of the V4 countries, and of the changes in the structure of their competitiveness based on relevant sub-indices, that in the period covered, the competitive positions of Poland, the Czech Republic and Hungary were primarily shaped by basic requirements. Efficiency enhancers also played a slightly greater role. However, the contribution of innovation and sophistication factors was only significantly higher in the Czech Republic.

With reference to the hypothesis put forward in the introduction to the article, it is justified to argue that in shaping their international competitive position, the V4 economies should rely more on innovation and sophistication factors as well as on efficiency enhancers. In the period covered, for the V4 countries the pillars directly related to innovation (pillar 11 and pillar 12) were characterised by negative (with one exception of pillar 11 for Poland) weighted contributions to the change in the overall GCI scores 
(see Tables 3 to 6). As regards the pillars illustrating efficiency enhancers, the situation is more complex as there were similar numbers of positive and negative weighted contributions to the change. Nevertheless, the presence of pillars' negative contributions indicates the need for economic policies oriented towards efficiency enhancers.

\section{References}

Bossak, J. (2000), Międzynarodowa konkurencyjność gospodarki kraju i przedsiębiorstwa. Zagadnienia teoretyczne i metodologiczne, [in:] Bossak, J., Bieńkowski, W. (eds.), Konkurencyjność gospodarki Polski w dobie integracji z Unią Europejska. Warszawa: Wydawnictwo SGH.

Ezalea-Harrison, F. (2005), On the competing notion of international competitiveness, 'Advances in Competitiveness Research', No. 13 (1), pp. 80-87.

Kancs, D. (2011), The economic geography of labour migration: Competition, competitiveness and development, 'Applied Geography', No. 31 (1), pp. 191-200.

Krugman, P. (1994), Competitiveness: A Dangerous Obsession, 'Foreign Affairs', No. 73 (2), pp. 28-44.

Misala, J., Misztal, P., Młynarzewska, I., Siek, E. (2008), Międzynarodowa konkurencyjność gospodarki Polski w okresie 1990-2007. Radom: Politechnika Radomska.

Molendowski, E. (2017a). An Internationally Competitive Economy: Poland Compared To The Visegrad Group Countries In The Post-Accession Period. 'Comparative Economic Research. Central and Eastern Europe’, No. 4/2017, pp. 5-17.

Molendowski, E. (2017b), International competitive position of the Polish economy against the backdrop of the Visegrad Group countries-changes in the post-accession period. Trends in the World Economy Vol. 9/2017, pp. 119-130.

Porter, M., Rivkin, J. (2012), The Looming Challenge to U.S. Competitiveness, 'Harvard Business Review', No. 90 (3).

Siebert, H. (2000), Zum Paradigma des Standortwettbewerbs. Tübingen: Mohr Siebeck.

Thore, S., Tarverdyan, R. (2016). The sustainable competitiveness of nations, Technological Forecasting and Social Change, No. 106, pp. 108-114.

WEF (2016). The Global Competitiveness Index Historical Dataset (c) 2005-2015. Geneva: WEF.

WEF (2017). The Global Competitiveness Report 2017-2018. Geneva: WEF.

Weresa, M.A. (2012), Systemy innowacyjne we współczesnej gospodarce światowej. Warszawa: Wydawnict wo Naukowe PWN.

Żmuda, M. (2016), Strategie pobudzania konkurencyjności Singapuru i Irlandii w świetle koncepcji państwa rozwojowego - wnioski dla gospodarek doganiajacych, 'Studia i Materiały. Miscellanea Oeconomicae', Year 20, No. 3, Vol. II.

Żmuda, M. (2017), Towards a Taxonomy of International Competitiveness, 'Journal of Management and Business Administration. Central Europe', Vol. 25, pp. 97-116.

Żmuda, M., Molendowski, E. (2016), W poszukiwaniu istoty konkurencyjności gospodarki narodowej: studium interdyscyplinarne. 'Finanse, Rynki Finansowe, Ubezpieczenia', No. 3 (81). 


\section{Streszczenie}

\section{Wpływ filarów konkurencyjności na pozycję konkurencyjną gospodarki Polski i krajów Grupy Wyszehradzkiej w okresie poakcesyjnym}

Artykuł jest prezentacją wyników analizy, której celem była ocena wpływu najważniejszych czynników (filarów) na międzynarodową pozycję oraz zdolność konkurencyjną gospodarki Polski i pozostałych krajów Grupy Wyszehradzkiej (GW-4). W badaniu podjęto próbę zweryfikowania hipotezy, że kraje GW-4 powinny w większym stopniu kształtować międzynarodową pozycję konkurencyjną gospodarek przez czynniki proefektywnościowe oraz proinnowacyjne. Pozycję konkurencyjną analizowanych gospodarek i jej zmiany określono wykorzystując raporty Global Competitiveness Report (GCR), publikowane przez World Economic Forum. Okres badawczy obejmuje lata 2004-2017, jednak w przypadku braku porównywalnych danych został zawężony do lat 2006-2017.

Artykuł kończy zestawienie najważniejszych wniosków wynikających z przeprowadzonej analizy.

Słowa kluczowe: międzynarodowa konkurencyjność gospodarki, filary konkurencyjności gospodarki Polski, Polska na tle państw Grupy Wyszehradzkiej 